\title{
Flawed Progress: Criticisms of Residential Institutions for Child Migrants in Australia and Policy Responses, 1939-1945
}

The archival records of the Dominions Office relating to child migration to Australia before 1939 are characterised by an almost complete absence of any sense of the need for any formal monitoring of the welfare of children sent overseas. In 1911, officials at the Local Government Board had stated that annual reports would need to be sent on the welfare and progress of individual child migrants up to the age of 16, if local Boards of Guardians were to be allowed to pay for children under their care to be sent to Fairbridge's proposed farm school at Pinjarra. ${ }^{1}$ To the extent that such reports were subsequently provided there are no indications that civil servants in the Dominions Office were aware of their contents. Instead, the belief that organisations involved in child migration were undertaking good work appears to have been reinforced more in the Dominions Office by formal visits to Pinjarra by public figures-including Leo Amery and Malcolm MacDonald-which were carefully prepared public events. At the start of 1937, the Fairbridge farm schools were regarded in the Dominions Office as one of the most successful forms of assisted migration since the passing of the Empire Settlement Act. ${ }^{2}$

Before the outbreak of war, however, the Dominions Office was starting to become aware of operational challenges that suggested a more

${ }^{1}$ See Notes, $17^{\text {th }}$ August 1911, and other correspondence and reports in TNA: $\mathrm{MH} 102 / 1400$.

${ }^{2}$ See note to Machtig, 22 $2^{\text {nd }}$ January 1937, TNA: DO35/686/4.

(C) The Author(s) 2021

G. Lynch, UK Child Migration to Australia, 1945-1970,

Palgrave Studies in the History of Childhood, https://doi.org/10.1007/978-3-030-69728-0_3 
complex picture to the idealised stories and pictures of children's transformation presented in the Child Emigration Society's annual reports. In February 1937, G.F. Plant, the Dominions Office civil servant who had served as a member of the Fairbridge Society Council, met with Winifred Cullis, Professor of Physiology at the University of London. Although publicly supportive of the Fairbridge scheme, Cullis wished to raise concerns she had about children of 'bad stock' being sent to Pinjarra who had no realistic hope of becoming productive citizens overseas. ${ }^{3}$ Plant rebuffed her criticisms internally in the Dominions Office, sharing the Fairbridge view that the whole point of the Society's work was to effect transformation in children by changing their environment. ${ }^{4}$ After having met Cullis himself, however, the Secretary of State, Malcolm MacDonald was said to have been alarmed by her accounts of two individual children sent to Pinjarra-one epileptic, the other said to have homicidal tendencies. Eric Machtig, then an Assistant Under-Secretary of State, noted MacDonald's view that Fairbridge's London office would need to be more careful in its selection of children if it were to avoid negative publicity for its work, an issue that MacDonald raised directly with Fairbridge's London office. ${ }^{5}$

Criticisms of Fairbridge's selection policy were made by other people around the same time. Little more than a week after Cullis's meeting with MacDonald, a conversation was recorded by Dominions Office officials with the then principal of Pinjarra, Dallas Paterson, who was visiting England. Paterson was soon to resign from his position after conflict with the London Society over his views that poor selection of children were leading to too many cases of former residents at Pinjarra failing to settle in work, becoming involved in criminality, falling pregnant or having other forms of emotional difficulty. ${ }^{6}$ The note of Paterson's conversation at the Dominions Office only recorded his proposal that the Fairbridge Society should change its selection policy to recruit 'the finest raw material'. However, later private communication between Charles Hambro, Chair of the Fairbridge London Society and Edward Cavendish, the

\footnotetext{
${ }^{3}$ Winifred Cullis, 'Fairbridge School in W. Australia', The Times, $23^{\text {rd }}$ February 1937; note of conversation with Cullis, $15^{\text {th }}$ February 1937, TNA: DO35/686/4.

${ }^{4}$ On this ethos, see Juvenile Emigration and the Farm School System, pamphlet produced by the Child Emigration Society, 1910, TNA: MH102/1400.

${ }^{5}$ Note by Machtig, $24^{\text {th }}$ February 1937, and MacDonald to Lumley, $17^{\text {th }}$ February 1937, TNA: DO35/686/4.

${ }^{6}$ Note of conversation with Paterson, $25^{\text {th }}$ February 1937, TNA: DO35/686/4; see also Sherington and Jeffrey, Fairbridge: Empire and Child Migration, pp. 145-147.
} 
Under-Secretary of State for Dominion Affairs, suggested that the Dominions Office were aware that Paterson was making wider criticisms of Pinjarra and were apparently reassured by Hambro that, where valid, his criticisms were already being dealt with. ${ }^{7}$ The view that Fairbridge should concentrate on sending a better class of child, more suited to leadership roles in Australia, was also put to Plant at the Dominions Office by Miss Gertrude Drayton, Secretary of the Victoria League. Drayton also claimed that dissatisfaction with Fairbridge's current work was also felt by Sir Geoffrey Whiskard, the UK High Commissioner in Canberra, and Lord Gowrie, Governor-General of Australia. ${ }^{8}$ The view of the Dominions Office, expressed both to Paterson and Drayton, was that organisational policy matters were a decision for the Fairbridge Society itself, and not something in which the Dominions Office could become involved. It was also noted within the Dominions Office that such a radical change to the type of children recruited by the Society would constitute a significant shift away from the original vision of Kingsley Fairbridge and might cause problems amongst those who had already made substantial donations to the Society on the basis of that.

Whilst these criticisms about Fairbridge's selection methods, and its mixed results at Pinjarra, did not appear to create any significant doubts in the Dominions Office about the fundamental value of the Society's work, further problems were soon to present themselves. In June 1937, Gordon Green, the Secretary of Fairbridge's London Society, and Charles Hambro alerted the Dominions Office to emerging difficulties in the trans-national governance of their organisation. ${ }^{9}$ Kingsley Fairbridge had incorporated the organisation's Western Australian committee prior to the incorporation of its London committee. This formally allowed the Western Australian body to act as an entity independent of the London society, although in practice it was dependent on it both financially and for the recruitment of children. A similar organisational division had now more recently occurred with the development of the Fairbridge farm school in New South Wales, where the local committee also established itself as an

\footnotetext{
${ }^{7}$ Hambro to Cavendish, $6^{\text {th }}$ December 1937, TNA: DO35/686/4. Hambro's letter, addressed to 'My dear Eddie', was sent to Cavendish's private address rather than formally to him at the Dominions Office.

${ }^{8}$ See note of meeting with Drayton, $16^{\text {th }}$ March 1937, and Plant to Drayton, $20^{\text {th }}$ March 1937, TNA: DO35/686/4.

${ }^{9}$ See, e.g., Memorandum by Green, $26^{\text {th }}$ June 1937 , and note of meeting on $28^{\text {th }}$ June 1937, TNA: DO35/691/5.
} 
incorporated body for tax reasons and had been able to initiate the development of the Molong farm school through substantial local donations. Whilst in principle the Fairbridge child migration programme could operate in a spirit of mutual collaboration between its London and Australian committees, in practice operational tensions that had always existed in these arrangements were becoming increasingly strained. The Western Australia committee was resisting attempts by the London office to develop the after-care of children leaving Pinjarra. In New South Wales the organisation's proposed articles of association gave the London society no representation on its committee and decisions had been made about the final location of the farm school without agreement from London. Issues between the London and New South Wales committees were ultimately resolved by the end of the summer, with the latter agreeing to having up to four members of its committee nominated by London, as well as giving the London committee the power to make the appointments of Molong's Principal and after-care officer. ${ }^{10}$ During this process, however, staff in the Dominions Office had expressed considerable reluctance to take any formal role in mediating between the London and the New South Wales committees, even less to be seen as the 'official big stick' which could be used by sending organisations in the United Kingdom to try to control the activities of receiving organisations in Australia. ${ }^{11}$ Instead, they sought more informally to encourage conciliatory efforts from London. The potential organisational difficulties of managing child migration as a trans-national initiative were, however, becoming clear.

Knowledge of problems with child migration was by no means limited to the UK Government. The report on the future of Pinjarra, compiled by T.H. Garrett of the Commonwealth Migration and Development Commission in 1928 had already noted significant conflict between the Child Emigration Society's London and Western Australian committees to the extent that the London committee had threatened not to send any more children unless it could exert more control over the work being done in Australia. ${ }^{12}$ In 1937, the Premier of New South Wales wrote to the Commonwealth Prime Minister, Joseph Lyons, to confirm his approval

\footnotetext{
${ }^{10}$ See Reid to Whiskard, $12^{\text {th }}$ August 1937, and Agreement between Fairbridge Farm Schools Incorporated, and the Fairbridge Farm Schools of New South Wales, $30^{\text {th }}$ September 1937, TNA: DO35/691/5.

${ }^{11}$ Note by Plant, $8^{\text {th }}$ July 1937, TNA: DO35/691/5.

12 'Report by T.H. Garrett on the Child Emigration Society', 16 ${ }^{\text {th }}$ March 1928, NAA.C: A461/C349/1/7.
} 
of the sending of assisted child migrants to Molong on the condition that effective medical checks be undertaken on child migrants before departure at Australia House given that his State Department of Labour and Industry had previously raised concerns about the health and fitness of children sent to Dr Barnardo's farm school at Picton. ${ }^{13}$ Questions about the quality of after-care at Pinjarra were further raised, in 1939, by an immigration official at Australia House who suggested to Gordon Green that the recent case of a teenager repatriated back to the United Kingdom by Fairbridge on grounds of unsatisfactory behaviour reflected less on the character of that boy than on inadequate after-care that had been provided to him. ${ }^{14}$ As was to be the case after the war, such knowledge held by Australian authorities was not always, as a matter of course, passed back to the Dominions Office or UK High Commission.

\section{Child Migration, the Onset of War AND FAILING INSTITUTIONS}

The outbreak of war caused considerable disruption to child migration programmes. Fairbridge's London office initially supported the UK Government's decision to suspend assisted migration, reportedly in part because it was concerned at the reputational damage to its work that would be suffered if a ship carrying children it had sent overseas was torpedoed. ${ }^{15}$ By 1940, the financial challenges of reduced numbers of children being received by its farm schools, and the start of overseas evacuation of British children through the Children's Overseas Reception Board (CORB), ${ }^{16}$ led Fairbridge to lobby the Dominions Office to allow it to send children overseas whom it had recruited before the start of the war. The Dominions Office agreed to this request in April, 1940, and then in September 1940, sought to apply pressure on the Children's Overseas Reception Board when it initially refused to give up some of its allocated

\footnotetext{
${ }^{13}$ Premier of New South Wales to Prime Minister, $2^{\text {nd }}$ April 1937, NAA.C: A461/ K349/1/7.

${ }^{14}$ Stables to Green, $18^{\text {th }}$ July 1939 , A659/1945/1/505.

${ }^{15}$ See note to Duke of Devonshire, TNA: DO35/703/5.

${ }^{16}$ On the emigration of children to Australia by the CORB, see Edward Stokes, Innocents Abroad: The Story of British Child Evacuees in Australia, 1940-45 (St Leonards, NSW: Allen \& Unwin, 1994).
} 
berths for Fairbridge children. ${ }^{17}$ However, the torpedoing of the City of Benares on 18th September, en-route to Canada, resulting in the deaths of 77 CORB evacuees, soon led to the wider CORB programme being suspended. Despite this the Dominions Office indicated that it was still willing to allow children previously recruited by Fairbridge to be sent overseas, but was prevented in doing so on grounds of the children's safety by the Treasury, before Fairbridge themselves indicated that it also wished to suspend migration of further children for the time being. ${ }^{18}$ This led to continued financial pressures on its farm schools, mitigated in the case of the Northcote farm school by the decision to allow children of Australian soldiers to be accommodated temporarily there during the war. ${ }^{19}$ Children remaining at Northcote were eventually transferred to Molong in 1944. Declining numbers also put increasing pressure on the work at Pinjarra. ${ }^{20}$ Before the suspension of the CORB programme, Brother Conlon sought to persuade the Australian Commonwealth Government to place CORB evacuees at Catholic institutions in Western Australia which he claimed, without any obvious grounds, could receive at least 250 boys and 250 girls. $^{21}$ This request was refused by the Australian Commonwealth Government on the basis that CORB evacuees had been sent on the understanding that they would be placed in private households, and not residential institutions. ${ }^{22}$ Even after the sinking of the City of Benares Conlon continued to press for 200 girls to be sent to Nazareth House, Geraldton and 300 boys to Christian Brothers' institutions in

\footnotetext{
${ }^{17}$ MacLeod to Green, $8^{\text {th }}$ April 1940, Kimber to Wiseman, $14^{\text {th }}$ August 1940 , and Wiseman to Syers, $18^{\text {th }}$ September 1940 , TNA: DO35/703/5.

${ }^{18}$ See note by Wiseman $5^{\text {th }}$ October 1940 , note by Wiseman $7^{\text {th }}$ October 1940 , note by Machtig, $10^{\text {th }}$ October; and Syers to Wiseman, $3^{\text {rd }}$ October 1940; Fairbridge was subsequently able to send a small group of five children to its farm school in British Columbia in the autumn of 1941 through contacts in the Admiralty, MacLeod to Hardie, $11^{\text {th }}$ September 1941, TNA: DO35/703/5.

${ }^{19}$ For notes and correspondence on this arrangement, and other proposals for mitigating costs from the loss of income with the suspension of child migration, see DO35/692/1. Dwindling numbers at Northcote led to the 42 remaining children there being transferred to Molong in December 1944 to save costs, Green to Secretary, $31^{\text {st }}$ January 1945, TNA: DO35/1138/M1019/1.

${ }^{20}$ Given the lack of opportunities for child migration during the war, Fairbridge also decided not to take up the offer of the donation of a property and land for it to establish a new farm school in New Zealand, TNA: DO35/698/5.

${ }^{21}$ Conlon to Foll, $2^{\text {nd }}$ July 1940, NAA.C: A659/1945/1/499.

${ }^{22}$ Minister of the Interior to Conlon, 24 ${ }^{\text {th }}$ July 1940, NAA.C: A659/1945/1/499.
} 
Western Australia, but was refused again by the Australian Commonwealth Department of the Interior on grounds on the unsafe shipping conditions. $^{23}$

At the same time as the Dominions Office was trying to persuade the Children's Overseas Reception Board to give some of its allocated berths to Fairbridge recruits, tensions arose again between Fairbridge's London and New South Wales committees. The latter decided to present the then Principal at Molong, Richard Beauchamp, with an ultimatum of resigning his post or face being suspended, acting without the prior agreement of the London Committee. When Beauchamp contacted the London office to complain he was resigning under duress, the London committee initially asserted its power by indicating that it was not prepared to accept this resignation. The London committee soon reversed this decision under encouragement from the UK High Commissioner, Sir Geoffrey Whiskard, and regretfully accepted Beauchamp's resignation. ${ }^{24}$ Whilst the Dominions Office understood that this action had been taken because of long-standing disagreements between Beauchamp and the New South Wales committee, it does not appear to have been informed by Fairbridge that its immediate cause was that the committee had received information indicating that Beauchamp was failing to maintain appropriate standards of sexual morality at the farm school by failing both to prevent sexual contact between boys and girls and to ensure appropriate punishment for 'homosexual offences'. ${ }^{25}$

On the basis of the information it had received, the Dominions Office responded to Beauchamp's resignation as another incident in which it needed to undertake an informal mediating role between Fairbridge's London and New South Wales committees, rather than as an issue that had a bearing on child migrants' welfare. Clearer concerns about some of the other residential institutions were soon to emerge, however.

In December 1942 Whiskard's replacement as UK High Commissioner in Canberra, Sir Ronald Cross, submitted a report to the Dominions

\footnotetext{
${ }^{23}$ Conlon to Honeysett, $1^{\text {st }}$ December 1940, Carrodus to Conlon, $20^{\text {th }}$ December 1940 , NAA.C: A659/1945/1/499.

${ }^{24}$ Telegram, UK High Commissioner to Dominions Office, $11^{\text {th }}$ September 1940, and telegram, Dominions Office to UK High Commissioner, 20 $0^{\text {th }}$ September 1940, TNA: DO35/692/1. Beauchamp had a long-standing relationship with the Fairbridge Society, having previously ran its field office in Glasgow.

${ }^{25}$ See Independent Inquiry into Child Sexual Abuse, Child Migration Programmes Investigation, Day 12 transcript, $12^{\text {th }}$ July 2017, pp. 94-99.
} 
Office of his impressions of informal visits to the Pinjarra and Tardun farm schools during a more general tour that he was making of Western Australia the previous October. ${ }^{26}$ Cross had relatively little to say about Pinjarra other than to compare it favourably to conditions at Tardun which, he noted, had not been visited by any representative of the UK Government since boys first arrived there in the summer of 1938. Cross's account of conditions there differed substantially from the positive account given by Conlon. ${ }^{27}$ Whilst the boys at Tardun generally appeared healthy, he was 'somewhat taken aback... to see a number of boys who had the appearance of ragamuffins, being barefooted and dressed in extremely old, untidy and dirty looking shirts and shorts'. Although smarter outfits were used when the boys later gave a concert in honour of their visitors, Cross speculated how the poor condition of their work clothing could be reconciled with the on-going maintenance funding being received by the Christian Brothers particularly as the labour used in the up-keep of the farm school was provided free of charge by both the Brothers and the boys and food costs would also be limited. The farm school was suffering from considerable over-crowding, as boys from the Christian Brothers' residential institution at Clontarf had been transferred there earlier that year when it was seconded for use by the Royal Australian Air Force. Accommodation at Tardun was described by Cross as being 'extremely rough' and often unclean, and still in one part only just nearing completion. Cross was particularly concerned by the Principal, Br Sandes, whom he found to be very vague on a range of administrative issues ranging from the financial budgets of the farm school, the effects of over-crowding on the boys' education and the Christian Brothers' approach to after-care. When pushed on future careers, the Principal speculated that many of the boys would probably want to remain working for the Brothers, which Cross found hard to reconcile with the principle that boys were being trained at Tardun as agricultural settlers. Whilst Cross commented that it was unlikely that another visit from a representative of the UK Government could be made to Tardun in the near future, given its isolated location more than 300 miles from Perth, he nevertheless felt that periodic visits of this kind would be 'in every way desirable'. In the absence of any such visit in the near

${ }^{26}$ 'Notes on visit to Tardun', $15^{\text {th }}$ December 1942, TNA, DO35/1138/M1020/1.

${ }^{27}$ See, e.g., Conlon to Wiseman, $21^{\text {st }}$ March 1941, TNA: DO35/691/1 which stated the child migrants at Tardun 'are doing well and have made a most favourable impression on all visitors, including the Government inspectors who visit the school at regular intervals'. 
future, however, Cross recommended that Catholic sending organisations be notified of these concerns with a view to them raising these issues with the Christian Brothers. He also proposed that the Australian Commonwealth Government be approached to obtain a report by Western Australian State officials on the welfare of the child migrants in the Brothers' institutions.

Cross's report was passed up through civil servants at the Dominions Office to the Parliamentary Under-Secretary of State, Paul Emrys Evans. Emrys Evans concurred with Cross's recommended course of action whilst also accepting his civil servants' suggestion that Bishop Griffin be made aware of the report's criticisms but discouraged from contacting the Christian Brothers until the Australian State report had been received. It was also noted that as the five-year maintenance agreement had nearly expired for most of the boys sent to Tardun, there might be little scope for effecting change at the institution before these finally ran out. ${ }^{28}$ Part of the value of the report from Western Australia State officials, it was assumed, would be that it would include some assessment from an official experienced in evaluating educational institutions who could offer an informed view on Br Conlon's claims about the value of Tardun as a vocational training institution. ${ }^{29}$

After a request for a State inspection report was passed on to the Western Australian Government via the Commonwealth Prime Minister's office, a senior official in the Western Australian Lands and Immigration Department, Francis McAdam, undertook an inspection of the Christian Brothers' institutions at Tardun, Bindoon and Castledare in April, 1943. ${ }^{30}$ McAdam, who actively supported the work of the Christian Brothers College in Perth, ${ }^{31}$ and who had no expertise on educational matters, produced reports that focused primarily on the material infrastructure and holdings of each institution, and offered only brief comments on the education and welfare of children. In addition to giving assurance that the terms of the UK Government's maintenance agreements for Castledare and Tardun were being 'carried out to the letter', McAdam offered

\footnotetext{
${ }^{28}$ See notes dated $5^{\text {th }}$ February, $8^{\text {th }}$ February, $9^{\text {th }}$ February, $10^{\text {th }}$ February and $16^{\text {th }}$ February 1943, TNA: DO35/1138/M1020/1.

${ }^{29}$ In 1944, Walter Garnett appeared to think that the training in trades at Tardun was relatively limited compared to Bindoon, see 'Farm Schools in Australia' in October 1944, TNA: DO35/1138/M1007/1/2.

${ }^{30}$ Correspondence and copies of the reports are held at NAA.C: A659/1945/1/499 and TNA: DO35/1138/M1020/4.

${ }^{31}$ Obituary of McAdam, Annual of Christian Brothers College, Perth, 1946.
} 
particularly effusive praise for Bindoon about which he commented that 'the present ambitious scheme of making practical provision for the future of migrant boys and state wards at Bindoon reflects credit on the community of Christian Brothers and its lion-hearted Superior, Br Keaney'. Attached to the copies of McAdam's reports sent to the UK High Commission in Canberra was a list of the child migrants who had been sent to Western Australia in 1938 and 1939, indicating their chosen occupation (including 'Farmer', 'Baker', 'Plumber', 'Farmhand' and 'Electrician'). No further information was given about the adequacy of the vocational training that would be provided to prepare the other boys for their indicated future occupation.

In his covering letter when forwarding these documents on to the Dominions Office, Sir Ronald Cross noted that McAdam's report did not address points that had concerned him from his own visit to Tardun, such as over-crowding, inadequate sanitary arrangements or lack of clarity about after-care arrangements. ${ }^{32} \mathrm{He}$ also commented that there was insufficient evidence that the settlement of boys on the land as farmers in their own right was being attempted to the same degree as had been indicated when Conlon had initially sought UK Government funding support. At the same time, Cross acknowledged, McAdam had not specifically been asked to report on the issues raised by him, and the fact that a new Principal had been appointed at Tardun might represent a change from its previous poor management.

Clement Attlee, as the new Secretary of State for Dominion Affairs, replied to Cross offering a more positive assessment and commenting that the reports indicated improvements at these institutions (although no information had been received by the Dominions Office about Castledare or Bindoon prior to this)..$^{33}$ As 25 of the child migrants were reported to being trained up as farmers and with land being cleared for them, Attlee commented that 'I feel doubtful whether more could have been done to settle the boys on the land'. Cross suggested that a follow-up visit to Tardun by an experienced official representing the UK Government should be made as soon as a convenient opportunity arose, and Attlee concurred. Other internal disagreements were also recorded within the Dominions Office. The Assistant Secretary, Robert Wiseman, commented that it is satisfactory that the Inspector should have found things in so

\footnotetext{
${ }^{32}$ Cross to Attlee, $24^{\text {th }}$ June 1943, TNA: DO35/1138/M1020/4.

${ }^{33}$ Attlee to Cross, $30^{\text {th }}$ July 1943, TNA: DO35/1138/M1020/4.
} 
good a condition'; in response, the Under-Secretary of State, Paul Emrys Evans, wrote that 'I do not think that Sir R. Cross feels that the situation is satisfactory although he thinks there has been an improvement'. ${ }^{34}$ Wiseman had already by then met with Bishop Griffin and Canon Craven to make them aware of Cross's initial criticisms and discouraged Griffin from contacting the Christian Brothers directly until the Australian State report had been received. ${ }^{35} \mathrm{He}$ met with Griffin again in August 1943 to indicate that the Australian report had been satisfactory and that a follow-up visit to the Christian Brothers institutions would be made by a representative of the UK High Commission. ${ }^{36}$ Wiseman also took the opportunity to discuss the possibility of the resumption of assisted migration in collaboration with the Catholic Council for British Overseas Settlement after the war, noting that it might be a year or two after the war's end before assisted migrants could again be sent to Australia.

Three weeks before Cross forwarded on McAdam's reports, the Dominions Office also became aware of significant problems at the Northcote farm school at Bacchus Marsh. A letter from Evelyn Baring, a Northcote trustee then working at the Foreign Office, had previously commended the excellent staff at Northcote led by the Principal, Colonel Heath. ${ }^{37}$ In early June 1943, however, Walter Garnett, now returned to the UK High Commission in Canberra as Official Secretary, wrote to Robert Wiseman about a number of problems that he had recently learned about at Northcote. ${ }^{38}$ By then, Garnett had a long history of involvement in migration matters, having served as the secretary to the 1924 Bondfield delegation whilst working for the Oversea Settlement Department and as one of the joint secretaries to the Economic Advisory Council's Committee on Empire Migration. ${ }^{39}$ From 1943 onwards, he was to become a pivotal figure

\footnotetext{
${ }^{34}$ Note by Wiseman, $19^{\text {th }}$ July 1943, and note by Emrys Evans, $26^{\text {th }}$ July 1943, TNA: DO35/1138/M1020/4.

${ }^{35}$ Note by Wiseman, $23^{\text {rd }}$ March 1943, TNA: DO35/1138/M1020/1.

${ }^{36}$ Note by Wiseman, $24^{\text {th }}$ August 1943, TNA: DO35/1138/M1020/4.

${ }^{37}$ Baring to MacLeod, $28^{\text {th }}$ May 1942, TNA: DO35/692/1. Baring was later to become the UK's Governor in Kenya at the time of the Mau Mau uprising.

${ }^{38}$ Garnett to Wiseman, $4^{\text {th }}$ June 1943, TNA: DO35/1138/M1019/1.

${ }^{39}$ See Garnett's account of the Bondfield delegation and report in Report on Child Migration (British and white alien), 17 ${ }^{\text {th }}$ March 1944, NAA.C: A689, 1944/43/554/2/5.
} 
in representing the UK Government in Australia on what were to become increasingly difficult issues concerning child migration. ${ }^{40}$

Garnett had been alerted to possible problems at Northcote after one of the cottage mothers had written with a series of complaints to Lady Gowrie, wife of the Australian Governor-General. Having seen this letter, Garnett decided to go to Melbourne where he met the Secretary of the Northcote Trustees and was able to establish more information about recent events. He learned that after two teachers at the neighbouring State school had been charged with sexually assaulting three girls from the Northcote farm school, the Principal, Colonel Heath, had been asked to resign towards the end of 1942 . Complaints had also been received about a high proportion of the 56 children who had so far been placed out in employment from Northcote and, when pressed about this before his resignation, Colonel Heath had reportedly said that when he was Principal at Pinjarra the results of the training provided were not as good as Fairbridge publicly claimed there either and that a number of former residents at Pinjarra had ended up in reformatories.

Garnett was also told that the Trustees had been increasingly sceptical about the value of a child migration programme in which children were accommodated in separate institutions with limited ability to mix with the wider community until they left the farm school. The Trustees also felt that agricultural training could well be of limited value for the boys at the school given the poor opportunities for career progression in agricultural work. Bad management at the dairy farm had led both to sickness amongst the children and the production of poor-quality dairy products. External dairy farm inspectors had indicated that problems had resulted in part from the farm school's attempt to run too large a dairy herd with poorly trained boys, where the work involved in simply managing the herd had prevented staff having enough time to train the boys properly. When ascertaining whether the State Child Welfare Department had inspected Northcote during this period, Garnett was also surprised to discover that State Child Welfare inspectors only had jurisdiction over State wards and so did not have any supervisory powers over child migrants.

\footnotetext{
${ }^{40}$ Garnett had also become involved in child migration issues soon after his appointment as an assistant to the British Government Representative in Canberra in 1931, trying to intervene to prevent the reduction of the Commonwealth Government subsidy for children at Pinjarra after this had been reduced by the Western Australian State Government, Garnett to Secretary, Dept of the Interior, $1^{\text {st }}$ September 1932, NAA.C: A659/1945/1/505.
} 
Overall, Garnett suggested, failings at Northcote might be less as a result of systemic problems within the Fairbridge scheme and more a result of a combination of local factors where Heath had both managed the farm school inadequately and received insufficient support and oversight from a relatively inexperienced local committee. In this regard, Garnett noted, similar problems could also be seen with the running of the farm school at Molong. Although, after making a return visit to Northcote in July 1943, Garnett gave a more optimistic report about prospects for the farm school under its new Principal, he added that problems with placing children in employment might well have been the result of poor initial selection by Fairbridge which led to Northcote being overloaded with 'difficult' cases. ${ }^{41}$ Garnett was later to revise this view, suggesting that these problems arose more from problems in management and after-care at Bacchus Marsh rather than the quality of children sent. ${ }^{42}$

When Wiseman shared the results of Garnett's report with the Northcote trustees in London, it became clear that there were problems with the sharing of information about conditions at the farm school. ${ }^{43}$ The Australian trustees had not apparently known about the critical reports about conditions at the dairy which had gone only to Heath, nor the fact that the new Principal had already been absent through a long period of ill health. Not only was communication between the different trans-national arms of this organisation poor, but those involved tended to attribute failings to parts of the system other than those in which they were directly involved. Whilst the Australian trustees blamed problems on poor selection of children in Britain, the British trustees blamed the difficulties with children's work placements on bad teaching at the local State school. Blame was also attributed, diplomatically, to those removed from the system-notably the retiring, Colonel Heath-rather than to those with whom different actors in the scheme still needed to co-operate. ${ }^{44}$ When approached with Garnett's report, Gordon Green initially acknowledged that he had already been aware of the case of the teachers prosecuted for sexual assault, but not about other problems at the farm school. He saw no problems in Fairbridge's selection of children and blamed failings at

${ }^{41}$ Garnett to Wiseman, 16 ${ }^{\text {th }}$ August 1943, TNA: DO35/1138/M1019/1.

42 'Report on Farm Schools in Australia', TNA: DO35/1138/M1007/1/2.

${ }^{43}$ See both Note by Wiseman on meeting with Gordon Green, $2^{\text {nd }}$ July 1943 , and notes following letter from Wiseman to Lord Grey, $3^{\text {rd }}$ July 1943, TNA: DO35/1138/M1019/1.

${ }^{44}$ See, e.g., Grey to Luxton, $29^{\text {th }}$ December 1943, TNA: DO35/1138/M1019/1. 
Northcote on Heath being kept in post for too long. Although Green thought that the British trustees had full confidence in the Australian trustees, the British trustees reported to Wiseman that they thought too many of the Australian trustees had been appointed because of their preeminence and not necessarily because of their suitability or active interest in the farm school.

Criticisms of Fairbridge's selection methods created tensions between Fairbridge's London office and Northcote's British trustees, as a result of which Gordon Green passed Wiseman a file of previous correspondence between Fairbridge and Northcote's trustees in Britain and Australia which documented a series of problems at the farm school over a number of years. ${ }^{45}$ In January 1939, Charles Hambro had written to Lord Grey to make him aware of criticisms made of Northcote by Helen Bentwich, then serving as Honorary Secretary for the United Kingdom Committee for the reception of refugee children from Germany. After visiting Northcote, Molong and Pinjarra, Bentwich told Hambro that she felt the system was failing by isolating children from local Australian communities, segregating boys and girls to too great a degree and not having enough opportunity to learn to manage a regular pocket money allowance. Northcote gave Bentwich particular concern because the future employment prospects for girls after leaving there seemed particularly poor-worse than if they had remained in the United Kingdom-and the girls were sufficiently unhappy there to tell her that they wanted to come back home from Australia. This problem, Hambro noted, might have resulted in part from the lack of sympathy towards the girls from the Principal's wife, Mrs Heath, which had also previously been a source of difficulty at Pinjarra.

In June 1941, Gordon Green had also written to Evelyn Baring noting both that he had just received half-yearly reports on children at Northcote a year late and that Northcote did not have any administrative officer in Britain who could deal with any queries from parents or guardians about the welfare of their child after emigration to Bacchus Marsh. Hambro followed this up a month later with a letter to Baring asking for more prompt half-yearly reports, monthly updates on any illness or movement of a child and annual after-care reports on children placed out in employment.

\footnotetext{
${ }^{45}$ See Green to Wiseman, $15^{\text {th }}$ October 1943, with enclosures, TNA: DO35/1138/ M1019/1.
} 
A letter from Green to Hambro in March 1942 indicated both that Fairbridge were already aware by then that Heath was to be removed as Principal of Northcote and that, whilst not ideal as a Principal, he had previously been able to serve for eight years at Pinjarra because he had been able to keep the local committee in Perth happy. A copy of a letter from December 1942 from the Australian trustees to Lord Grey, held in Fairbridge's file, noted the problems with finding work placements for children given their behaviour, the fact that Heath's tenure as Principal had been marked by discipline based on fear rather than affection, and that whilst the trustees appreciated Heath's efforts, he lacked any understanding of child psychology. As a consequence, many of the old boys of the farm school had no desire to return to it in their holidays.

In January 1943, Green wrote to Northcote's Australian trustees pointing out that as Fairbridge were not prepared to take the organisational responsibility of becoming the full legal guardians of children when they were sent to Australia - because of the potential liabilities involved-it was essential that sufficient regular information be provided from Northcote back to Fairbridge's London office for this to be passed back to children's parents and guardians in Britain. Despite it being hoped that Heath would continue the practice of regular reporting back that he had maintained at Pinjarra, Fairbridge's London office had received no information at all about the welfare and progress of children at Northcote for periods of between 18 months and two years since his appointment. Green was also concerned to discover that girls had been sent out to work from Northcote at the age of 14, despite Fairbridge's undertaking that they would not be placed into work from the farm school until nearly the age of 16. Green had followed this up with a letter to Lord Grey in February 1943 indicating that before further children be sent to Northcote, once shipping routes were open again, a formal agreement would need to be made between Fairbridge and Northcote to ensure that such regular reporting was maintained. Such concerns were accentuated, Green noted, by cases such as a mother who had contacted Green after receiving a letter from her son indicating that he had become a labourer after leaving Northcote despite it being recognised in earlier school reports that he was capable of more advanced agricultural education. As the mother pointed out, if she had known that he was not to receive better education and training she would not have allowed him to go to Australia. The last letter in the file, dated 22nd September 1943, concerned a boy from Northcote who had ended up before a Magistrate after the appointment of Heath's 
replacement, and where the Magistrate's criticisms indicated the need for after-care from Northcote to be more effectively organised.

Fairbridge's correspondence with Northcote therefore demonstrated both that Fairbridge's London office and Northcote's British trustees had knowledge of substantial problems at the farm school pre-dating Garnett's report in the summer of 1943. The file also suggested that there had been long-standing problems with standard of care, post-migration reports and after-care at Northcote which had not previously come to the attention of the Dominions Office and which had also occurred to some extent at Pinjarra. When Wiseman wrote to Garnett in December 1943 to make him aware of the file-although not its full contents-he remained supportive of the broad Fairbridge model. ${ }^{46}$ Wiseman also noted, however, that whilst the Fairbridge ideal of transforming children's lives through moving them to new environments was undoubtedly valid, this ideal could be undermined by poor conditions in receiving institutions which needed to be run on principles of 'constant supervision, constant care and constant scrutiny'. In response, Garnett sought to defend Northcote's operations in Australia - a stance he was to take up on other occasions in the future when criticisms were made from London. ${ }^{47}$ It was not fair, he wrote, to expect Northcote staff in Australia to deal with problematic children of whom they had been given insufficient detail about their backgrounds. But even faced with this challenge, Garnett commented, the local Northcote trustees were 'justly proud' of the improvement in children placed at their farm school, as they upheld the Fairbridge principle that the right kind of environment could enable a child to progress regardless of their previous background.

\section{The 'Pinjarra dossier' and the Garnett Report}

At the same time as Garnett and Wiseman were engaging in this correspondence, further problems arose in relation to the Fairbridge farm schools. In late November 1943, Sir Charles Hambro met with the Secretary of State for Dominion Affairs, Viscount Cranbourne, expressing concern at rumours about the management of Pinjarra including its apparent insistence that children at the farm school be prepared for agricultural

\footnotetext{
${ }^{46}$ Wiseman to Garnett, $7^{\text {th }}$ December 1943, TNA: DO35/1138/M1019/1.

${ }^{47}$ Garnett to Wiseman, 22 ${ }^{\text {nd }}$ January 1944, TNA: DO35/1138/M1019/1.
} 
work regardless of their preferred future career. ${ }^{48}$ In view of the concern being raised by these rumours, Hambro felt it would be beneficial if Walter Garnett be asked to make an inspection visit to Pinjarra as soon as possible. Robert Wiseman took a sympathetic view of this request, noting that it had always been intended that a follow-up inspection visit to Western Australia be undertaken in view of Sir Ronald Cross's comments on Tardun and that 'any difficulty which has so far been felt in sending him to Western Australia has been the difficulty of sparing staff from the High Commissioner's Office at Canberra' ${ }^{49}$ Planning for this inspection visit soon became mired in discussions about the relative importance of this visit given other demands on the High Commission's time and the extent to which the Dominions Office should take responsibility for over-seeing conditions at receiving institutions in Australia. Whilst Eric Machtig took the view that it was not possible to spare Garnett's time for such a visit, the Secretary of State, Viscount Cranbourne over-ruled him, stating that the circulation of unsatisfactory rumours about Pinjarra merited further investigation by representatives from the High Commission and the Australian Commonwealth Government-albeit one that required no 'tearing hurry'. ${ }^{50}$

With staff shortages delaying any arrangements for Garnett's inspection visit the following spring, Gordon Green sent Robert Wiseman a dossier of documents in April 1944 detailing problems at Pinjarra from both former staff members and residents. ${ }^{51}$ Although compiled by Fairbridge prior to Hambro's meeting with Cranbourne the previous November, Fairbridge's London officers had been cautious about circulating a copy of it before taking legal advice on whether its contents might be libellous. The dossier itself contained a series of detailed complaints about the ways in which the Fairbridge committee in Western Australia had created an environment at Pinjarra in which children were given little or no opportunity to develop interests, education or training beyond agricultural and domestic work, had been transferred to a local reformatory for minor infractions and were placed out in exploitative work placements with little opportunity for advancement. Concerns were also raised about the ability

\footnotetext{
${ }^{48}$ See note $26^{\text {th }}$ November 1943, TNA: DO35/1138/M1007/1/2.

${ }^{49}$ Note by Wiseman, $29^{\text {th }}$ November 1943, TNA: DO35/1138/M1007/1/2.

${ }^{50}$ Note by Machtig, $1^{\text {st }}$ December 1943 , and note by Cranbourne, $2^{\text {nd }}$ December 1943 , TNA; DO35/1138/M1007/1/2.

${ }^{51}$ Extract from letter from Garnett, $9^{\text {th }}$ March 1944, and Green to Wiseman with enclosures, $21^{\text {st }}$ April 1944, TNA: DO35/1330.
} 
of cottage mothers to provide individual attention to children when caring for more than 12 children in their 'cottage' home, and the ways in which children were transferred between cottages with little or no concern for helping them to maintain relationships with siblings or friends. Allegations of verbal and physical abuse by cottage mothers at Pinjarra were passed on to the Dominions Office a year later. ${ }^{52}$ Lack of effective sex education was also seen by one former member of staff as a significant cause of problems in the mixed school environment and had led to early pregnancies for some former girls from the farm school. One letter in the dossier, from a god-parent who was sponsoring a boy at Pinjarra, expressed disillusionment with the farm school's ethos, seeing in its refusal to encourage his wider interests an attitude of not wanting 'to give the children ideas above their station' ${ }^{53}$ As the author put it, in language that was to be reflected in the 1946 Curtis Report, whilst children at Pinjarra 'have been better housed, fed and clothed than they would have been in their conditions here [in the United Kingdom], I very much wonder whether they have been happier except as regards their material condition'.

Wiseman noted that the dossier revealed 'a most distressing state of affairs' and arranged for a copy to be sent as quickly as possible to Garnett in Canberra to inform decisions about the planning of his inspection visit to Western Australia. ${ }^{54}$ Soon after this, however, the Dominions Office became less confident of the wisdom of such a visit, as Wiseman was informed by Sir Roger Dalton, a member of Fairbridge's New South Wales committee, that the local committees for Molong, Northcote and Pinjarra were now in communication with each other about their dissatisfaction with on-going attempts by Fairbridge's London office to exercise control over the running of their farm schools. ${ }^{55}$ Whilst Wiseman and Machtig

\footnotetext{
${ }^{52}$ See Tempe Woods to Wiseman with enclosures, $5^{\text {th }}$ April 1945, TNA: DO35/1138/ M1007/1/2, which notes that although the current cottage mothers at Pinjarra were of a better kind, in the recent past 'very unsuitable cottage mothers have been allowed to remain on the farm. They have spoken very roughly to the children and hit them. Girls in their teens have been beaten. Children have been locked in rooms'.

${ }^{53}$ Merryless to Hart, $28^{\text {th }}$ January 1944, TNA: DO35/1330.

${ }^{54}$ Note by Wiseman, $9^{\text {th }}$ May 1944, and Wiseman to Garnett, $20^{\text {th }}$ May 1944, TNA: DO35/1330.

${ }^{55}$ Notes by Wiseman, $26^{\text {th }}$ May 1944 and $7^{\text {th }}$ June 1944, TNA: DO35/1330. The Dominions Office believed that Dalton, the UK Government's Senior Trade Commissioner in Australia, represented the London Society on Fairbridge's New South Wales Committee but Gordon Green later claimed that Dalton was not put forward for that role by London nor had they had much contact with him (see 'Report on Farm Schools in Australia by $\mathrm{Mr}$
} 
supported Dalton's view that the Dominions Office should be cautious about undertaking any imminent inspection, given the risks of becoming caught up in the conflict between Fairbridge's London and Australian committees, Paul Emrys Evans argued that if conditions at Pinjarra were as bad as had been claimed then the Dominions Office had 'definite responsibilities' to investigate. ${ }^{56}$ Viscount Cranbourne suggested that Fairbridge's London office send a representative to Australia to resolve the conflict as quickly as possible so that no controversy would arise during a forthcoming planned visit to Australia by the Duke of Gloucester. ${ }^{57}$ The decision to send Garnett to Western Australia in the midst of this internal dispute within Fairbridge was supported by Sir Ronald Cross. It was also given further weight by a visit to the Dominions Office from Reuben Wheeler, who met with Emrys Evans, Wiseman and C.W. Dixon, an Assistant Under-Secretary of State, to pass on his impressions from visits to the farm schools at Bacchus Marsh, Picton and Molong. Wheeler told this meeting 'that both the Commonwealth and the U.K. Governments must be held in some way responsible for not realising how things had been going wrong at Northcote and he thought also at Pinjarra'. Wheeler argued that it was the duty of each Government to be aware of conditions at these institutions and that 'each school ought to be inspected at least once a year on behalf of each Government'. ${ }^{8}$ Paul Emrys Evans agreed that Wheeler's recommendation should be implemented, and Sir Ronald Cross concurred with this on the basis that this take the form more of an informal annual visit than a formal inspection. ${ }^{59}$ As Wiseman noted, though, for a member of staff at the UK High Commission in Canberra to undertake annual inspections of Northcote, Pinjarra, Molong, Tardun and Picton would represent a significant investment of administrative time. ${ }^{60}$

W. Garnett and Comments of the General Secretary of the Fairbridge Farm Schools, Inc', TNA: DO35/1138/M1007/1/2).

${ }^{56}$ See notes by Machtig, $7^{\text {th }}$ June 1944 and Emrys Evans, 9 ${ }^{\text {th }}$ June 1944, TNA: DO35/1138/M1007/1/2.

${ }^{57}$ Note $9^{\text {th }}$ June, TNA: DO35/1138/M1007/1/2.

${ }^{58}$ See minute of meeting with Wheeler, $6^{\text {th }}$ July 1944 , also confidential reports by Wheeler on visits to Bacchus Marsh, $8 / 9^{\text {th }}$ May 1944 , Molong, $19^{\text {th }}$ May 1944 , and Picton, $21^{\text {st }}$ May 1944, TNA: DO35/1138/M1007/1/2.

${ }^{59}$ Note by Wiseman, $12^{\text {th }}$ July 1944, and by Emrys Evans, $5^{\text {th }}$ September 1944, TNA: DO35/1138/M1007/1/2.

${ }^{60}$ Note by Wiseman, $18^{\text {th }}$ August 1944, TNA: DO35/1138/M1007/1/2. 
Before Garnett undertook his visit to Western Australia, further criticisms about standards at Pinjarra were also received by the UK High Commission in Canberra. In 1943, the Australian Commonwealth Government had established an inter-departmental committee to explore the prospects for post-war immigration, which in turn established a subcommittee specifically to examine the potential for resuming child migration. ${ }^{61}$ The sub-committee approached Caroline Kelly, an anthropologist who had previously undertaken government advisory work on welfare and immigration matters, to produce a report examining both existing organisational support for child migration and prospects for future development. Kelly produced a national survey of current child migration schemes in 1944, from which an extract on Pinjarra was sent to Garnett confidentially by the Commonwealth Department of the Interior. ${ }^{62}$

In this confidential report, Kelly made significant criticisms of the governance of Pinjarra, which she said needed completely overhauling if the farm school were to continue to receive Commonwealth Government funding. She began by noting that the current Acting Principal (who had originally joined the staff as a gardener and then been appointed to this post from being the former Principal's clerk) did not have appropriate training for this senior role. At least, Kelly commented, the Acting Principal could be commended for his honesty, unlike other members of the Committee that she met. Kelly found the Perth Committee elusive and uncooperative, and was later informed indirectly that this was because they had assumed that she was 'a minion of London doing a little more spying'.

Despite difficulties in eliciting information from the Perth Committee, Kelly was able to visit Pinjarra itself. There she noted that there was a high turnover of staff, and an uneven approach to the care of children amongst the cottage mothers. Staff that the London committee described as supporting children's vocational training at the farm school were not in post, and the wife of the chairman of the Western Australia committee told Kelly that there was little point in providing bursaries for children at Pinjarra to pursue grammar school education as they would only feel out of place when mixing with their 'social superiors'. Time after school that

${ }^{61}$ See Carrodus to Director-General, Ministry of Post-War Reconstruction, $30^{\text {th }}$ November 1943, NAA: A441, 1952/13/2864; also Kelly's work on European refugees in New South Wales at NAA: Al336, 39459.

${ }^{62}$ See note by Peters with enclosures, $26^{\text {th }}$ June 1944 , NAA: A436, 1945/5/54. The Caroline Kelly archives are held at the University of Queensland Library. 
children living in their own homes might normally use for homework was taken up with chores. After leaving school at the age of 14, boys were kept on at Pinjarra as trainees and Kelly noted that there was pressure to keep them there after the age of 16-when they would normally be placed out in external labouring jobs-in order to keep Pinjarra's farm running. Similarly, after the age of 14 , girls were retained as trainees, which in practice involved them in undertaking domestic tasks to support the farm school rather than receiving any further training in domestic science. As a consequence, their skills when placed out in work after the age of 16 were limited to general 'housework'. Kelly also found the committee negligent with regard to limiting sexual contact between boys and girls. An on-site hostel for former residents of the school offered little management of its accommodation for older boys and girls. Whilst there were many cases of Fairbridge girls becoming unmarried mothers, the committee reportedly dealt with this only through expelling these girls and placing them in local Foundling Homes rather than responding more pro-actively to prevent such cases. Kelly also cited, supportively, a psychiatric assessment undertaken of several children at Pinjarra in 1936 which claimed that far too many children were being sent from the United Kingdom who were either 'mental defectives' or had some other problematic hereditary psychological trait.

Sir Ronald Cross telegrammed the Dominions Office confirming the receipt of this extract from the Kelly report and noting that it confirmed that 'all charges referred to in the [Fairbridge] dossier are within knowledge of the Commonwealth Government'. Cross also summarised Garnett's impressions from visits he had made to Picton, Bacchus Marsh and Molong with Wheeler earlier that spring before Wheeler had travelled to London, which suggested problems both with the composition of the local Fairbridge committees, the lack of effective after-care at Northcote and Molong and the possible need to end co-education at the Fairbridge schools (as had already happened at Picton) ${ }^{63}$ In view of the Kelly report, Cross concluded, Garnett should now definitely proceed to visit Pinjarra and Tardun, where for the former the issues of problems with its local management and the training provided to children seemed far more pressing than on-going struggles between the London and Western Australian

${ }^{63}$ See also 'Confidential report on visit to Northcote Children's Farm School, $8 / 9^{\text {th }}$ May 1944', TNA: DO35/1138/M1007/1/2, which Wheeler had handed over to the Dominions Office at his London meeting. 
committees ${ }^{64}$ A copy of Cross's telegram was also shown, by Paul Emrys Evans, to the acting chairman of Fairbridge's London committee, the Conservative MP, Sir William Brass, who had also served as a former Parliamentary Private Secretary to Leo Amery. ${ }^{65}$

Garnett visited Pinjarra, and the Christian Brothers' institutions in Western Australia in the late July and early of August of 1944. The first substantial document that he sent to the Dominions Office after this was a lengthy rebuttal — endorsed by the High Commissioner — of allegations made in the 'Pinjarra dossier' ${ }^{66}$ Garnett recognised that there were aspects of Fairbridge's Western Australian committee which needed revising. Like the committees for the farm schools at Bacchus Marsh and Molong, the Western Australian committee largely consisted of elderly men, appointed on the basis of their preeminent public positions, but without specific qualifications for over-seeing farm schools of this kind. In Western Australia, this had led the committee to take some rigid views and not always to be as helpful to promising children in its care as it could have been. At the same time, however, Garnett commented, the London committee's anxiety to monitor the work being done in Australia had led to threats of withholding children or funds from the Australian institutions which had bred mistrust and resentment towards the London Society. Many of the specific allegations in the dossier, Garnett noted, were made by two disgruntled former employees (although one of them had in fact paid his own fare back to England to raise concerns with the London committee) and he questioned the accuracy of some of their claims having reviewed records at Pinjarra itself. ${ }^{67}$ Much of the weight of their complaints, Garnett observed, was that children were not being given a wide enough range of vocational opportunities even though this was something

${ }^{64}$ Cross to Dominions Office, $28^{\text {th }}$ June 1944, TNA: DO35/1138/M1007/1/2.

${ }^{65}$ Note by Wiseman, $12^{\text {th }}$ July 1944, TNA: DO35/1138/M1007/1/2.

${ }^{66}$ Garnett to Wiseman, with enclosures, $23^{\text {rd }}$ August 1944, TNA: DO35/1330; also telegram from High Commission to Dominions Office, $15^{\text {th }}$ August 1944, TNA: DO35/1138/ $\mathrm{M} 1007 / 1 / 2$..

${ }^{67}$ The Dominions Office subsequently received a letter from the Chair of the Society for the Oversea Settlement of British Women, vouching for the credibility of one of the complainants, a former after-care worker at Pinjarra, Miss Tempe Woods (Thompson to Wiseman, $9^{\text {th }}$ April 1945), Wiseman's handwritten note on the letter is 'Please don't bother to reply'. Tempe Woods had herself written to Wiseman summarising her previous concerns with Pinjarra on $5^{\text {th }}$ April 1945: TNA: DO35/1138/M1007/1/2. 
that the Fairbridge farm schools in Australia never set out to achieve. That one of these complainants had lamented the lack of opportunities for children at the school to be taught music was, in Garnett's view, indicative of a failure to understand the purpose and limits of the education being provided at a farm school. To avoid placing young girls in vulnerable positions in isolated rural placements, or the occasional failure to ensure employers paid trainees' wages, would require a substantial re-working of the whole scheme. Whilst Garnett felt that the scheme could only work better in the future with a more constructive relationship between the London and Australian committees, implicit in his comments was a sense that interference from the United Kingdom in the affairs of Australian organisations reflected an unreconstructed attitude which failed to recognise the growing autonomy of Australia as a Dominion. This sentiment was regarded with some sympathy in the Dominions Office. ${ }^{68}$

In October, Garnett submitted his full report on the farm schools, including an Appendix on the Christian Brothers' institutions in Western Australia, which followed the instruction that he should give particular attention to the issue of child migrants' training. ${ }^{69}$ Noting that numbers at these institutions (other than those run by the Christian Brothers which also admitted Australian children) had declined significantly as a result of the cessation of child migration during the war, Garnett presented his report both as an assessment of current practice and an evaluation of potential for the future resumption of these schemes.

In terms of evaluating the effectiveness of the schemes so far, Garnett noted that 1071 children had been sent to Pinjarra since its opening with 825 being assessed as having 'made good' (i.e., being in stable employment and/or married). The remainder were variously categorised as 'definite failures', 'doubtful failures', 'still at school', 'lost touch' or 'no record'. Of these, 25 had been sent to reformatories from Pinjarra. Although the State Child Welfare Department found that most of their misdemeanours arose either from misunderstandings with staff or lack of sympathetic management by employers, Garnett interpreted this more in terms of Pinjarra sometimes lacking staff who could deal with 'difficult children'.

\footnotetext{
${ }^{68}$ See note by Dixon, $2^{\text {nd }}$ November 1945, also Garnett's acknowledgement (in 'Report on Farm Schools in Australia') of grounds for grievance of Fairbridge's Western Australian Committee and his recommendation that the London Society no longer seek to have the final say on senior appointments in the farm schools, TNA: DO35/1138/M1007/1/2.

${ }^{69}$ William Garnett, 'Report on Farm Schools in Australia', para 35, TNA: DO35/1138/ $\mathrm{M} 1007 / 1 / 2$.
} 
Only 76 children had so far been placed out in employment from the Northcote farm school and a high proportion of them had left their placements without notifying the school. Garnett noted that many of those considered unsuccessful in their work placements had received excellent reports whilst at the farm school itself. Of the 59 children placed in employment from Molong, around half had joined the armed forces and it was generally said that the children were reluctant to continue in agricultural work and showed little loyalty to their employers. In the case of Picton, 940 boys had so far been placed out in employment, either joining the armed services or mainly remaining in agricultural work. The 700 female child migrants who had left Dr Barnardo's Homes' institutions in New South Wales were, in the majority of cases, married, with the rest mainly in domestic service or the armed services.

A clear assessment of the farm schools' effectiveness was made harder by war-time conditions, Garnett argued, both because of the growth of better-paying war-time industries that were more attractive than farm work and because of the option of joining the armed services themselves. The focus on these farm schools on training children for agricultural labour or domestic service constituted the core mission on which they had been founded and claims, for example, by the Fairbridge's London Society that children would receive vocational training according to their talents had been misleading. The fact that Dr Barnardo's Homes in New South Wales seemed to have less difficulty with their children than the farm schools associated with Fairbridge was attributed potentially to Barnardo's longer organisational experience with child-care and the fact that its child migrants were already under the charity's care and training in the United Kingdom before coming to Australia.

Despite the clear mission of the farm schools to provide training for rural life, Garnett noted that the evidence of the inter-war period in Australia had been that it was generally economically unviable to attempt to settle immigrants on their own land as farmers unless they had their own capital. The Windham delegation's optimism about the potential for settling young British farmers in Australia had therefore not been borne out by economic reality and very few of those leaving farm schools had gone on to establish themselves as farmers in their own right. Given that these economic conditions were unlikely to change, Garnett argued, it was more realistic in the future to think of the farm schools as providing training for children for a range of occupations for rural life in addition to agricultural labour. This would also help to address the evident 
dissatisfaction of child migrants who found the agricultural work that they were directed towards unattractive. Better training in agricultural theory should nevertheless be given, however, as farm managers at Bacchus Marsh and Molong had been unqualified to do this and too often the need for children to support the day-to-day running of the farm was prioritised over more advanced training. More generally, educationally able children should be given more opportunities to advance beyond the primary level of education typically provided at the farm schools, supported where necessary by hostels that could accommodate trainees who were receiving secondary or technical education away from the farm school. Whilst this would constitute a shift away from the farm schools' original mission, Garnett argued that this was a necessary response to anticipated new welfare provisions in the United Kingdom which would reduce the number of children available for emigration and 'raise the standard of treatment which public opinion will expect of them'. 'It will be difficult', he wrote, 'to justify a scheme which determines the careers of children for them before they are of an age to have developed any predilections of their own' and 'public opinion in the United Kingdom will be unlikely in the future to favour schemes under which children are sent overseas... to undertake work which Australians themselves are reluctant to perform' ${ }^{70}$

Garnett recommended that to deliver this revised mission, greater attention needed to be paid to the appointment of Principals in future, who at the farm schools associated with Fairbridge too rarely had any previous experience of child-care work. Poor relations between Fairbridge's London and Australian committees could be addressed by more effective representation of the London Society on the Australian committees and the possible appointment of a liaison officer who would be able to give first-hand accounts of child migrants' treatment to the London office. Australian committees should also have a greater representation of members (including women) with experience of working with children, including at least one child psychologist. The recruitment of appropriate cottages mothers had proven to be an increasing problem, with both the high turnover of staff in these roles and poor appointments known to have a harmful effect on children. A possible solution to this would be to make such posts more attractive to better qualified women who would be relieved to

\footnotetext{
${ }^{70}$ On seeing Garnett's report, Dr Barnardo's Homes also sought to broaden training offered in New South Wales beyond agricultural work, see Kirkpatrick to Hart, ML: MLMSS.9025, Box 13.
} 
a large degree of domestic duties normally associated with the role. In the absence of more appointments of workers with child-care training due to limited financial resources, the farm schools should seek to have at least one member of staff with suitable child-care training who could supervise the cottage mothers. After-care officers were in post at Pinjarra and Picton. But at Bacchus Marsh and Molong, reliance was still primarily placed on checking children's welfare by correspondence-a system which the Windham delegation had considered inadequate more than 20 years before. Garnett recommended that after-care officers should be appointed if not already in post, and that their work should be extended to include interviews with prospective employers and inspection of their work places prior to children being placed with them. Effective record-keeping of children after arrival in Australia was essential and was generally being well done by the farm schools, however there was a notable lack of these at the institutions run by the Christian Brothers. Garnett remained uncertain about the value of sending too much case information with a child to Australia, as he saw the danger of this information being used inappropriately by staff directly involved in the child's care outweighing the likely benefits of such information being shared. More generally, Garnett was critical of the tendency of the farm schools to operate as isolated institutions that provided too few opportunities for child migrants to mix with local children and communities and which therefore prepared them poorly for life beyond the institution. More effort, he wrote, should be put into helping child migrants participate in local activities and attend local schools outside of the farm school.

Garnett's assessment of the Christian Brothers' institutions in Western Australia was mixed. On the one hand, the provision of a wider range of training in trades at Bindoon and the training of Christian Brothers as teachers (mainly at the order's Strathfield College in Sydney) offered advantages over the more limited training and largely unqualified staff at the other farm schools. He also noted the Brothers' claim that a third of the boys who had completed secondary school had gone on to complete the early secondary level qualification, the Junior Certificate, a rate which was said to compare favourably with other state schools. The involvement of boys in the construction of new buildings at Bindoon was also seen as a useful part of their vocational training. At the same time, Garnett had strong reservations. The standard of accommodation at Castledare and Tardun was particularly poor (in stark contrast to the recently built Nazareth House at Geraldton), and the lack of female help at Castledare 
made it particularly unsuitable as an institution for receiving young children. Without further improvement Castledare was not, Garnett concluded, an appropriate place for further British child migrants to be sent-a view with which Redmond Prendiville, the Archbishop of Perth, reportedly concurred. Accommodation at Tardun remained 'primitive' and was still incomplete and insufficient for the number of boys being kept there. Garnett also observed that the retention of boys without pay at Tardun up to the age of 18 offered little educational benefit to them. More generally, their training seemed to be subordinated to the use of their labour to generate income from the farm to alleviate the considerable overdraft built up during its development. ${ }^{71}$ The particularly isolated location of Tardun, and the fact that the quality of its land meant that it would not have been used for this purpose had it not been gifted to the Brothers, also made it far from ideal as a place to receive child migrants before school-leaving age. Very few records of individual children appeared to be kept, and the quality of after-care-devolved to local parish priests-was unclear.

When forwarded a copy of Garnett's report, Gordon Green replied that the problems described at Pinjarra reflected the Western Australia's committee resistance to pressure from London for appropriate staff to be appointed. He also noted that the Salvation Army reformatory fortunately appeared to be a more 'kindly place' for the Fairbridge children that had been expelled there. ${ }^{72}$ Similar dissatisfaction in New South Wales at the results of children placed out in work from Molong was, Green claimed, again a result of failure to accept appropriate oversight from London.

Green was unhappy with the notion that boys should be placed in farm work, and girls in domestic service, simply as a benefit to Australian society. He argued that 'to coerce Fairbridge boys and girls, whatever their tastes or capabilities, into agricultural or domestic work, would certainly mean a serious injustice to the individual and would invalidate the beneficence of Fairbridge care and custody of the child'. He added that contact with Old Fairbridgeans who had returned to the United Kingdom with the armed services had confirmed that in very many cases, those leaving Pinjarra had gone on to very poorly paid farm jobs in isolated areas in

\footnotetext{
${ }^{71}$ See also note by Ives, $31^{\text {st }}$ May 1943, TNA: DO35/1138/M1020/2 which observes that claims for maintenance payments for boys at Tardun suggested that fewer were leaving there than was the case at Picton or the farm schools connected to Fairbridge.

${ }^{72}$ Green to Wiseman, $31^{\text {st }}$ August 1945, and Report on Farm Schools in Australia by Mr W. Garnett and Comments of the General Secretary of the Fairbridge Farm Schools, Inc., TNA: DO35/1138/M1007/1/2.
} 
which 'the despised farm labourer had little contact with the master and the master's family'. When asked by an after-care officer from Pinjarra why a Fairbridge trainee was being paid nearly half the wage of Australian-born workers at the same farm, the employer reportedly replied, 'Ah, but he is only a Fairbridge boy'.

Given such experiences, Green noted, it was unsurprising that those leaving Pinjarra would seek to move away from farm work. Too many children had been taken from poor backgrounds in Britain only to become an 'underprivileged class' in Australia 'out of which only those with exceptional ability have been able to climb into a happier economic climate'. The farm schools at Bacchus Marsh and Molong were also problematic in their expectation of 'docility and uniformity' amongst the children in their care, and without greater control over operations in Australia, the London Society would be unable to ensure that the best interests of children were being served. The model of more diverse training in trades reportedly provided by the Christian Brothers would, Green suggested, be best taken up as a model by Fairbridge in the future.

Whilst he concurred with Garnett's assessment about the likely reduction in the supply of children from extremely poor backgrounds after the war, Green nevertheless anticipated that there would still be a ready supply of 'illegitimate children' who 'have no place in a normal family' and for whom emigration to the Dominions would offer 'a shelter against the harsh disadvantages of illegitimacy'. Green did, however, challenge a claim made by Garnett that the Western Australian committee were justifiably unhappy with the London committee for failing to provide expected numbers of children for Pinjarra once the other farm schools opened. Contrary to the suggestion that Pinjarra had been starved of expected recruits because the London Society had over-stretched itself with the opening of new farm schools, Green countered that recruitment to Pinjarra had fallen because the London Society was unhappy with standards and after-care there and that the Western Australian committee had, by that stage, built up sufficient financial reserves for reduced recruitment not to cause them financial difficulty.

Garnett's encouragement of better relations between the London and Australian committees failed to take account, Green argued, of the fact that the Australian bodies seemed largely able, on past history, to refuse direction from London. This left Fairbridge's London committee with responsibility for the children it sent overseas but no power over their care. This could only be resolved with a re-drawing of the legal basis of 
Fairbridge operations in Australia which would make the London Society the legal centre for their work. In the absence of any resolution of this unsatisfactory situation, Green argued that both the UK and Australian Governments should play a more active role in ensuring proper protection of children at these farm schools. Without more control from London, Green also questioned whether any more child migrants should be sent to the Fairbridge farm schools in Australia to suffer at the hands of 'obscurantist committees' with placing children out in foster care a preferable option to this. Garnett, when forwarded a copy of Green's comments, expressed scepticism about a number of his claims and recalled a submission from the Fairbridge Society to the Economic Advisory Council whilst he acted as a secretary for it, stating that the Society's aim was for the training up of agricultural workers and there was no need to supply children for other kinds of work. ${ }^{73}$ It would be more gracious, Garnett suggested, if the London Society recognised that its original mission was out-of-date rather than placing all the blame for the narrow vocational training at the farm schools on the Australian committees.

Composing a memorandum on Green's response, Wiseman took the view that it offered an unduly negative view of the Australian committees whom, he noted, the UK High Commission believed were responsive to improving the farm schools. ${ }^{74}$ Whilst a common charter of principles agreed by all the Fairbridge committees could be a useful initiative, this could only be based on a principle of the committees being equal bodies and any attempt by London to exert control over Australian bodies would, he thought, be disastrous. Much of the poor outcomes with placing child migrants in agricultural work could be attributed to war-time conditions, and if in future shortcomings were identified at the farm schools by visits such as those undertaken by Garnett and Wheeler, or by State welfare officials, 'it is likely that the Australian committees would respond to the suggestions without difficulty'. It was not entirely clear, however, on what evidence Wiseman's optimistic view was based.

The view that greater control from London over the Australian committees was impractical was endorsed by a meeting between John Parker MP, the new Parliamentary Under-Secretary of State for Dominions Affairs in the Attlee Government, Sir John Stephenson, Deputy

\footnotetext{
${ }^{73}$ Garnett to Wiseman, $15^{\text {th }}$ January 1946, TNA: DO35/1138/M1007/1/2.

${ }^{74}$ Memorandum by Wiseman, $31^{\text {st }}$ October 1945 , TNA: DO35/1138/M1007/1/2.
} 
Under-Secretary of State, Wiseman and Miss Wall, ${ }^{75}$ a representative from the Children's Branch of the Home Office. ${ }^{76}$ The Home Office became drawn into these discussions after Fairbridge's London committee had formally requested advice from the Home Office on revising its charter and constitution in line with current standards of child welfare. This meeting was the first occasion in which the Home Office was to become involved in direct discussions with the Dominions Office about child migration policy, reflecting the fact that, up to that point, this had been understood primarily as a part of central government policy on assisted migration rather than on children's out-of-home care.

In preparing for the meeting, Sir John Stephenson wrote an internal note indicating that whilst the proposal that Fairbridge's London Society should have legal control over the Australian committees was not feasible, he nevertheless sympathised with their argument that they needed to be satisfied that their obligations to children and their guardians were being properly discharged once the children were overseas. The difficulty that Fairbridge's London committee had in exerting control over child migration was, Stephenson commented, indicative of a similar challenge facing the UK Government:

In fact, these particular issues raise a wide general issue of policy. In present conditions, is it right that the Government here should not exercise greater responsibility? In other words, is it right that the migration of children from this country should be handed over to a private society to organise without any complete power of control by the Government beyond their power to make occasional investigations and call for reports from the Society? There can be no doubt that the original idea of the Scheme... is sound. But it is for consideration whether the maintenance of a plan of this kind should now be left to charitable private enterprise, the part of Government being limited to

${ }^{75}$ The role of Miss Wall, and later Mary Rosling, at higher administrative levels in the Home Office in work relating to the care of children should be understood in the context in which women made up a very small proportion of higher administrative staff within the civil service in this period (see Kelsall, Higher Civil Servants, p. 175).

${ }^{76}$ Minute of meeting at the Dominions Office, $18^{\text {th }}$ December 1945 , TNA: DO35/1138/ M1007/1/2. Prior to this meeting, the Home Office Children's Branch had seen copies both of Garnett's original report and Green's response and held a short summary of this on file (TNA: MH102/1401). As this file was on proposals for future arrangements for Fairbridge, the summary of Garnett's report held by the Home Office did not make any reference to the Christian Brothers. 
certain financial contributions and a general but not very effective power of supervision. ${ }^{77}$

Such concerns were, by then, not merely raised by the Australian experience, but also by critical reports that the Dominions Office had received about the Fairbridge Prince of Wales farm school in British Columbia. ${ }^{78}$

In response, Parker wrote that he agreed that the Fairbridge case raised wider policy questions relating to the governance and oversight of institutions receiving child migrants. ${ }^{79}$ This was particularly the case given indications from the Australian Commonwealth Government that it was interested in a considerable expansion of child migration following the end of the war. Without specifying what form it might take, Parker supported the creation of a 'more formal machinery' in the United Kingdom to 'keep a watch on all of the child migration schemes to Australia' which would involve representatives from the Dominions Office, the Australian High Commission in London and those organisations sending child migrants. In Australia, State Government representatives should be appointed to management committees of receiving institutions, along with representatives of other welfare organisations, and periodic inspections should also be made by staff from the Commonwealth Government and UK High Commission in Canberra. Whilst seeing child migration as having served a useful purpose which would continue, for a limited number of children, for many years to come, Parker proposed that UK Government funding support for Fairbridge farm schools be brought to an end if they did not broaden their training. Sending organisations should recognise the 'Dominion status' of receiving bodies, however, and should not direct control over them, just as the UK Government no longer sought control over her Dominions. Given the likely pressures to resume child migration in the near future, Parker recommended that

${ }^{77}$ Note by Stephenson, $29^{\text {th }}$ November 1945, TNA: DO35/1138/M1007/1/2.

${ }^{78}$ Criticisms about the 'administration, methods and outcomes' of the Prince of Wales farm school were initially raised in a review of the CORB evacuation scheme to Canada (see 'General Review of the CORB Scheme in Canada, 1940-1944', TNA: DO35/1140/ M1156/36). This led to further inquiries through the UK High Commission in Canada which established that recent reviews had identified serious failings at the farm school in terms of staff appointments and behaviour, its isolation and approach to training and problems with the sexual behaviour of those leaving the farm school (see note by Dixon, $14^{\text {th }}$ November 1944, TNA: DO35/1137/M894/1).

${ }^{79}$ Note by Parker, $18^{\text {th }}$ December 1945, DO35/1138/M1007/1/2. 
arrangements for the proper governance, oversight and delivery of child migration work needed to be put in place as quickly as possible. 'It will create a very bad impression', he noted, if child migration were delayed 'because of difficulties which up to now have been kept out of public view'.

In the event, though, limited staffing resources at the UK High Commission in Canberra meant that no regular inspections of receiving institutions were made by its staff when assisted child migration resumed in the post-war period. In the absence of such direct inspections, British policy-makers were to remain largely reliant on institutional approval and inspection reports generated by Australian State officials-information which was often shaped by the particular interests and working relationships operating between State officials and voluntary societies on the ground. In one sense, reliance on reports from 'regional' inspectors reflected existing practice within the Home Office, in which civil servants undertaking administrative and policy work in its Children's Department rarely, if ever, undertook any direct visits to local authorities and voluntary societies and based their decisions on reports from the Home Office Inspectorate. ${ }^{80}$ It was only some years into the post-war period, however, before it became clear that Australian State inspectors might be interpreting institutional conditions for child migrants quite differently to standards used by Home Office inspectors.

\section{'THE ORIGINAL IDEA OF THE SCHEME... IS SOUND': Interpretative Frames and Policy-Making}

The war years therefore heralded a significant shift in understanding in the Dominions Office of the need for better governance and more careful monitoring of the institutions to which child migrants were being sent in Australia. From the generally positive presumptions made about the delivery of child migration schemes in 1939, the notes by Stephenson and Parker in the winter of 1945 showed that there had been a significant move towards recognising the need for more careful monitoring of the training and after-care of child migrants, including an active role for the United Kingdom and Australian Commonwealth and State governments. Despite this change in attitude, a wider assumption of the beneficial effects of child migration remained.

${ }^{80}$ J.A.G. Griffith, Central Departments and Local Authorities (London: George Allen \& Unwin, 1966), pp. 371-81. 
Given evidence of failings in the schemes that had gathered in the war years, the persistence of this assumption might seem remarkable. Although no settled view seemed to have been reached as to whether difficulties in Australia arose from poor selection of children in the United Kingdom, the Dominions Office had seen repeated evidence of problems within organisational structures, in the selection and oversight of staff, in standards of institutional care and after-care, in the range and quality of training given and of the experiences of child migrants when placed out with employers.

Despite this, the long-standing assumption of the benefits of child migration, reinforced through the past 30 years of reviews of empire settlement policy, provided a framework through which these problems were not seen as fundamentally undermining the value of this work. Rather, they were, perceived as temporary problems, arising from particular circumstances or the failings of particular individuals, rather than endemic in the system of child migration itself. Optimism for its future was thus maintained. Both the reports by Caroline Kelly and Walter Garnett had suggested that whilst there had been past failings at farm schools, these should be treated on the principle of 'what's past is past'. Such a willingness to write off past shortcomings made sense if it was assumed that the fundamental principle of child migration was sound and that such shortcomings need not be repeated in the future. Garnett's willingness to accept that there would inevitably be failures with individual child migrants again was understandable if the schemes were, in general, seen as beneficial. In this same spirit, policy-makers' concerns were eased by assurances from trusted figures that conditions for child migrants would improve and hope for the future of the work was renewed whenever failing managers of receiving institutions were replaced. Such confidence tended to be reinforced by British policy-makers' reliance on written inspection reports produced in Australia, whose authors (including State immigration officials with an institutional interest in maintaining assisted migration) provided their own interpretative gloss on the inherent value of these schemes. The systemic problems inherent in such a trans-national welfare initiative were therefore interpreted as contingent quirks in a policy in which those in government continued to keep their faith.

Such positive presumptions towards child migration work foreclosed more critical inferences that could obviously have been drawn from the material already at hand for policy-makers. No one in the Dominions Office or UK High Commission appears to have been led by the Fairbridge 
file on Northcote to ask how such problems had persisted there for so many years without their knowledge. Attlee was happy to believe that things were reasonably well at the Christian Brothers' institutions despite the evidently limited value of McAdam's reports and the minimal information provided about child migrants' vocational training. Although confidence in Fairbridge's work appeared to have been shaken temporarily in the Dominions Office following its receipt of the Fairbridge dossier in May 1944, this was soon restored by the rebuttal of much of the dossier by the UK High Commission. Whilst Garnett's rejection of these criticisms was argued in some detail, there remained grounds for remaining unsure whether all was entirely well given that Garnett had not personally visited former Pinjarra residents placed out in work and had too easily attributed complaints to staff falling out with the Western Australian committee. The claim in his 1944 report that a substantial number of former residents had 'made good' by finding stable employment was not subjected to any critical scrutiny in the light of Green's claims of what former Pinjarra residents had told him about how they were marginalised and under-paid by the farmers who took them on. Although there was a hardening of opinion in the Dominions Office about the need for more regular government monitoring of institutions in Australia, this was seen as a safeguard for ensuring the effective delivery of a programme still assumed to have a useful social role. Generalised notions of the potential benefit of child migration thus provided the frame within which specific evidence of its failures was understood. As John Parker put it, where problems had clearly been established, these needed to be rectified so that public confidence in the value of this work was not lost. The reputation of this workgiven that it was fundamentally a social good-needed to be protected.

The importance of the interpretative frames through which civil servants and politicians understood the information they received about child migrants in Australia can also be seen in terms of what they believed constituted problems in this context. The fundamental understanding of child migration as an opportunity for education and training that would fit a child for a productive life as an imperial citizen meant that evidence of shortcomings in this training in the Fairbridge dossier and reports by Kelly and Garnett aroused strong concern in the UK High Commission and Dominions Office. Child migration was, in Gordon Green's words, thus understood as a 'serious injustice to the individual' if it acted against the ability of the child to make some decision about their future career in accordance with their ability or led to British children effectively being 
forced into menial roles that Australians were not prepared to take. The strength of feeling about this was evident in both Green's and Parker's willingness to withdraw support for children being sent to Fairbridge farm schools after the war unless training was broadened and allowed children greater scope to follow their interests and aptitudes. Similarly there was a consensus in the Dominions Office and the UK High Commission that if child migrants were to be assimilated effectively as citizens of British Dominions they could not live most of their childhoods in self-contained institutions with little contact with local communities, families or other children. By comparison, although Garnett recognised the need to address the problem of retaining appropriately skilled cottage mothers, there was little or no internal discussion within the Dominions Office of the likely effects on children of a high turnover of cottage mothers or the appointment of cottage mothers unsuited to providing appropriate emotional care for children. This emphasis on child migration as a form of vocational and civic training, and the comparative lack of emphasis on the quality of care of children, was to continue to be a feature of thinking about child migration amongst some supporters of empire settlement work well into the post-war period.

The other interpretative frame that proved significant for how child migration was perceived by British policy-makers was the wider movement towards greater political freedom for Britain's Dominions. In contrast to a backward-looking colonialism, valuing the autonomy of Australian governmental and voluntary bodies and trusting in their good-will to achieve appropriate standards seemed a far more progressive position to policymakers in the Dominions Office and UK High Commission. Aversion to strict oversight and control from Britain was evident not only in responses to attempts by the Fairbridge Society in London to act as the effective centre of operations for the farm schools, but in Cross's suggestion that annual inspections to receiving institutions in Australia be re-cast more as friendly visits. It is interesting to note that whilst such discomfort with any hint of continuing colonial control from Britain may have been felt amongst some British civil servants and politicians, it was not necessarily shared by their Australian counter-parts. Reuben Wheeler-in 1944-was perfectly happy to propose that the British Government undertake formal inspections of institutions for child migrants.

Whilst presumptions about the inherent value of child migration, and the need to respect the autonomy of the Dominions, still fundamentally 
underpinned British policy-makers' attitudes, the experiences of war-time failures had at least begun to make them more aware of the need to maintain some form of oversight of this work. The policy environment in which this was to take place, though, was about to change significantly as a result of the transformation of the structures of children's out-of-home care arising from the work of the Care of Children Committee led by Myra Curtis.

Open Access This chapter is licensed under the terms of the Creative Commons Attribution 4.0 International Licence (http://creativecommons.org/licenses/ by $/ 4.0 /$ ), which permits use, sharing, adaptation, distribution and reproduction in any medium or format, as long as you give appropriate credit to the original author(s) and the source, provide a link to the Creative Commons licence and indicate if changes were made.

The images or other third party material in this chapter are included in the chapter's Creative Commons licence, unless indicated otherwise in a credit line to the material. If material is not included in the chapter's Creative Commons licence and your intended use is not permitted by statutory regulation or exceeds the permitted use, you will need to obtain permission directly from the copyright holder.

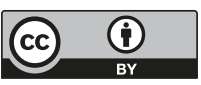

